\title{
Pelatihan Gejog Lesung pada Pemuda Dusun Gunturan, Triharjo, Pandak, Bantul Sebagai Upaya Pelestarian Budaya Bangsa
}

\author{
Wasis Suprapto ${ }^{1}$, Dodik Kariadi ${ }^{2}$ \\ wasissoeprapto@gmail.com \\ Bimbingan dan Konseling \\ STKIP Singkawang
}

\begin{abstract}
Bantul is one of the areas in the special region of Yogyakarta which is rich with traditional art one of them is art gejoglesung. This folk art comes from the sound of pounded alupukulkan regularly on large woods made like a boat called mortar. In general, dimples made of jackfruit wood or munggur. Nowadays gejoglesung art began to be abandoned by its lover because it is unable to compete with modern art. Therefore, we are moved to preserve the art of gejog mortar in order not to become extinct. One way is to hold gejoglesung training on youth youthgunturan, triharjo, pandak, bantul. The method of implementing the training is done through three stages of preparation, implementation, and follow-up. The preparation stage includes socialization, participant data collection, and training design. Implementation phase includes acceptance of participants, practice training, gejog art performances mortar. Theresults ofthis trainingwas able to foster back the sense of brotherhood, togetherness, cooperation, responsibility, nationalism among gejoglesung players themselves. This training was followed not only young men but also children, even parents participate and enliven the arts of the people. Gejog lesung training is a medium to represerve Bantul art that is almost extinct eroded by the times.
\end{abstract}

Keywords: Gejog Lesung, Youth, Bantul

\begin{abstract}
Abstrak: Bantul adalah salah satu daerah di daerah istimewa yogyakarta yang kaya dengan kesenian tradisionalnya salah satunya adalah kesenian gejog lesung. Kesenian rakyat ini berasal dari suara alu yang dipukulpukulkan secara teratur pada kayu besar yang dibuat seperti perahu yang disebut lesung. Pada umumnya, lesung dibuat dari kayu nangka atau munggur. Dewasa ini kesenian gejog lesung mulai ditinggalkan pencintanya karena kalah bersaing dengan kesenian modern. Oleh sebab itu, kami tergerak untuk melestarikan kesenian gejog lesung agar tidak punah. Salah satu caranya adalah mengadakan pelatihan gejog lesung pada pemuda pemuda dusun gunturan, triharjo, pandak, bantul. Metode pelaksaan pelatihan ini dilakukan melalui tiga tahap yaitu persiapan, pelaksanaan, dan tindak lanjut. Tahap persiapan meliputi sosialisasi, pendataan peserta, dan desain pelatihan. Tahap pelaksanaannya meliputi penerimaan peserta, praktik pelatihan, pementasan kesenian gejog lesung. Hasil pelatihan ini ternyata dapat memupuk kembali rasa persaudaraan, kebersamaan, kerjasama, tanggung jawab, nasionalisme antar pemain gejog lesung itu sendiri. Pelatihan ini ternyata diikuti tidak hanya pemuda pemuda saja namun juga anak-anak, bahkan orang tua pun turut serta meramaikan kesenian rakyat tersebut. Pelatihan gejog lesung adalah sebuah media untuk
\end{abstract}


kembali melestarikan kesenian Bantul yang hampir punah tergerus oleh perkembangan zaman.

Kata Kunci: Gejog Lesung, Pemuda, Bantul

\section{ANALISIS SITUASI}

Indonesia adalah negara yang memiliki banyak khasanah budaya. Kondisi ini tersebar diberbagai penjuru tanah air tanpa terkecuali. Setiap daerah di negeri ini memiliki khasanah budaya yang begitu beragam baik dalam bentuk tarian, lagu, seni pertunjukan, alat musik, dan lain sebagainya. Ironisnya, hampir semua warisan nenek moyang tersebut kini tengah diambang kepunahan. Hal ini terlihat dari banyaknya pemberitaan diberbagai media massa baik cetak maupu elektronik bahwa warisan bangsa ini banyak di klaim negara lain.

Klaim negara lain memang bukan isapan jempol semata. Ada banyak sekali contoh klaim yang dialami bangsa Indonesia mulai dari makanan, tarian, lagu, seni pertunjukan, dan lain sebagainya. Seperti ditulis Lazuardi di halaman Tribunnews.com Sabtu 21 Februari 2015 setidaknya ada 10 kesenian Indonesia yang pernah diakui Malaysia. Kesepuluh kesenian itu yaitu Batik, Lagu Rasa Sayange, Reog Ponorogo, Wayang Kulit, Kuda Lumping, Rendang Padang, Keris, Angklung, Tari Pendet dan Tari Piring, dan Gamelan Jawa. Situasi seperti pemberitaan tersebut pada dasarnya adalah alarm bagi masyarakat Indonesia pada umumnya untuk lebih peduli terhadap keberadaan kesenian yang ada. Kepedulian tersebut tentu tidak hanya terbatas pada tahap tahu tentang kesenian daerahnya tapi hal yang lebih penting adalah melestarikan kesenian tersebut.

Upaya pelestarian kesenian asli Indonesia dapat dilakukan diberbagai penjuru negeri. Semua daerah di Indonesia seyogyanya memiliki ragam keseniannya yang khas atau membedakannya dengan dearah lain. Khas ini yang sebetulnya harus diangkat dan dilestarikan agar klaim-klaim yang pernah dilakukan oleh negara lain tak kembali terulang. Satu diantara beberapa daerah di Indonesia yang terus berbenah untuk kembali mengangkat kesenian daerahnya adalah Kabupaten Bantul di Yogyakarta.

Kabupaten yang satu ini sejatinya memiliki ragam kesenian daerahnya yang khas. Satu diantara beberapa kesenian yang khas itu adalah Gejog lesung. Sesuai dengan namanya kesenian uniknya ini menggunakan lesung dan alu sebagai instrumen permainannya. Penggunaan lesung dan alu menandakan bahwa corak mata di daerah ini rata-rata bermata pencaharian sebagai seorang petani padi. Jaman dulu baik lesung dan alu memiliki posisi tawar utama dalam sistem pengolahan hasil tanaman padi. Padi jaman itu dirontokkan dengan 


\section{Wasis Suprapto ${ }^{1}$, Dodik Kariadi ${ }^{2}$}

memasukkannya ke dalam lesung kemudian di tumbuk menggunakan alu. Potret penggunaan lesung dan alu ini dilakukan karena keterbatasan teknologi pertanian masyarakat saat itu.

Seiring bertambahnya waktu dunia pun berubah. Perubahan itu terjadi di semua elemen kehidupan baik dalam bidang sosial, ekonomi, politik, teknologi, dan bidang-bidang lainnya. Perubahan ini terjadi oleh beragam faktor salah satunya adalah keberadaan teknologi yang berkembang begitu pesat (Aesijah, 2011). Perkembangan teknologi ini pun ternyata turun berdampak pada bidang pertanian warga. Warga yang dulunya menggunakan lesung dan alu sebagai media perontoh padi seolah harus mengganti kearifan lokal mereka dengan teknologi perontoh padi. Alih teknologi ini disadari atau tidak ternyata berpengaruh pada keberadaan kesenian gejong lesung (alu dan lesung) (Wahyudiarto \& Kusmayati, 2003) khususnya di masyarakat Bantul. Petani kini telah banyak beralih fungsi menggunakan teknologi dalam proses perontohkkan padi. Kondisi ini membuat keberadaan gejog lesung makin terpinggirkan bahkan terancam punah. Oleh sebab itu, diperlukan usaha agar kesenian ini dapat eksis di era modern seperti saat ini.

Generasi muda punya peranan penting dalam pembangunan suatu negara. Maju dan mundurnya sebuah negara tidak dapat dilepaskan dari keberadaan pemuda termasuk dalam konteks ini adalah keberadaan keseniaan di negeri ini (Budiono, 2018). Kesenian di Indonesia banyak yang mengalami kepunahan dan hal ini pun disinyalir akan terus berlanjut sampai detik ini. oleh sebab itu, diperlukan peran serta pemuda agar kesenian daerah tidak mengalami kepunahan. Pelibatan pemuda dalam konteks ini dapat dilakukan dengan memberikan pelatihan. Pelatihan ini dapat diimplementasikan pada semua jenis kesenian termasuk didalamnya gejog lesung di Dusun Gunturan, Triharjo, Pandak, Bantul. Kesenian gejog lesung di dusun ini pun ternyata tidak banyak diketahui oleh pemuda setempat. Geranasi terakhir yang memainkan kesenian ini pun tinggal sudah semakin sedikit jumlahnya. Hal ini diperparah oleh makin modernnya permainan saat ini sehingga anak-anak muda lebih menggandrunginya. Gejog lesung tentu perlu diangkat dan lestarikan kembali agar kesenian ini tak mengalami nasib sama seperti kesenian lain yang berada diujung kepunahan.

\section{SOLUSI DAN TARGET}

Berdasarkan kajian tentang analisis situasi di atas maka solusi dan target dari pelatihan kesenian gejog lesung di Dusun Gunturan, Triharjo, Pandak, Bantul adalah sebagai berikut: 
1. Memberikan sosialisasi bagi para pemuda di Dusun Gunturan, Triharjo, Pandak, Bantul untuk turut terlibat aktif dalam upaya pelestarian kesenian gejog lesung agar kesenian ini tidak punah lekang oleh zaman.

2. Untuk mengoptimalkan peran pemuda dalam upaya pelestarian budaya bangsa maka diperlukan langkah nyata dengan memberikan kegiatan pelatihan. Kegiatan pelatihan ini nantinya akan melibatkan beberapa pihak baik penggiat budaya Bantul, Sanggar Tari, ibuibu PKK, termasuk didalamnya adalah pemuda.

3. Kegiatan pelatihan ini diharapkan dapat memberikan motivasi dan dorongan bagi kesenian-kesenian lain di Kabupaten Bantul pada khususnya dan Indonesia pada umumnya untuk terus bergerak memajukan kesenian. Langkah ini perlu dilakukan untuk menghindarkan kepunahan juga untuk menghindarkan klaim-klaim yang pernah dilakukan negara lain atas beberapa kesenian lokal Indonesia.

\section{METODE PELAKSANAAN}

Kegiatan pelatihan gejog lesung pada pemuda pemuda di Dusun Gunturan, Triharjo,

Pandak, Bantul dilaksakan melalui beberapa tahapan sebagai berikut:

1. Persiapan. Pada dasarnya persiapan adalah tahapan awal sebelum kegiatan pelatihan kesenian gejog lesung di Dusun Gunturan, Triharjo, Pandak, Bantul dilaksanakan. Tahap persipan dilakukan dengan melakukan beberapa hal sebagai berikut:

a. Berkoordinasi dengan pihak Desa Triharjo untuk melaksanakan kegiatan pelatihan di desa tersebut

b. Sosialisasi pada pemuda pemuda dan masyarakat di Dusun Gunturan, Triharjo, Pandak, Bantul

c. Melakukan pendataan peserta pelatihan gejog lesung

d. Bekerjasama dengan seniman Bantul untuk melakukan pelatihan atau pendampingan kegiatan pelatihan bagi pemuda pemuda di Dusun Gunturan

e. Berkerjasama dengan ibu-ibu PKK untuk berkolaborasi dalam kegiatan pelatihan gejog lesung

f. Bekerjasama dengan sangar tari di Bantul untuk berkolaborasi bagi para pemuda agar kegiatan pelatihan gejog lesung ini menjadi semakin menarik sehingga punya nilai jual lebih dari pelaksanaan gejog lesung pada umumnya.

g. Pembahasan desain pelatihan (materi, waktu pelaksaan, jadwal kegiatan, alur kegiatan, dan hal-hal yang berkaitan denngan penyelenggaraan pelatihan) 
h. Pengadaan bahan pendukung pelatihan khususnya alu sebagai unsur utama penunjang kegiatan termasuk juga alat-alat bantu penunjang lainnya

i. Menyiapkan alat rekam dan sejenisnya untuk kegiatan dokumentasi kegiatan pelatihan

j. Rapat persiapan terakhir dengan stakeholder terkait agar kegiatan pelatihan dapat berjalan dengan baik

2. Pelaksanaan. Tahap kedua yang sangat penting untuk menunjang kegiatan pelatihan kesenian gejog lesung pada pemuda pemuda di Dusun Gunturan, Triharjo, Pandak, Bantul adalah pelaksanaan. Tahap ini dilakukan melalui beberapa kegiatan sebagai berikut:

a. Pembukaan pendaftaran bagi para peserta pelatihan

b. Membuka, menjelaskan teknis, dan penyampaian materi

c. Praktik pelatihan gejog lesung secara menyeluruh

d. Pementasan gejog lesung

e. Evaluasi kegiatan

3. Tindaklanjut. Tahap terakhir dari rangkaian kegiatan pelatihan gejog lesung pada pemuda pemuda di dusun Gunturan, Triharjo, Pandak, Bantul adalah tindaklanjut. Tahap ini dilakukan dengan melakukan kerjasama dengan pemerintah Desa Triharjo untuk terus melestarikan kegiatan sejenis secara berjenjang. Selain itu, juga dilakukan melalui media massa seperti facebook dan blog.

\section{HASIL DAN LUARAN}

Berikut ini adalah langkah-langkah yang dilakukan untuk merealisasikan kegiatan program pelatihan kesenian Gejog Lesung di Dusun Gunturan, Triharjo, Pandak, Bantul:

1. Sosialisasi Program

Kegiatan awal yang sangat penting dalam pelatihan kesenian gejog lesung di Dusun Gunturan, Triharjo, Pandak, Bantul adalah sosialisasi. Kegiatan sosialisasi ini dilakukan untuk menyampaikan tujuan dari keinginan untuk melestarikan kesenian gejog lesung pada pihak Desa Triharjo baik pemerintah desanya maupun pemudanya. Kegiatan sosialisasi pada tahap ini dapat dilihat seperti pada gambar di bawah ini: 


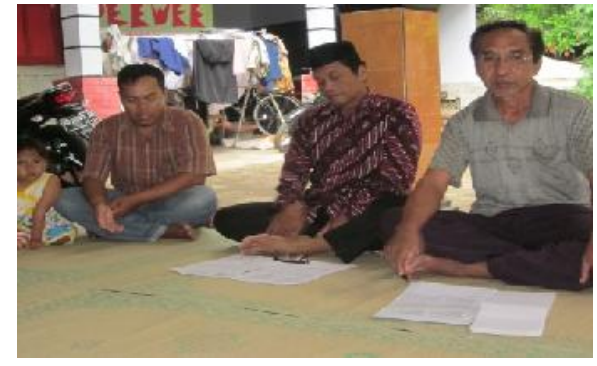

Gambar 1. Sosialisasi ke Aparat Desa

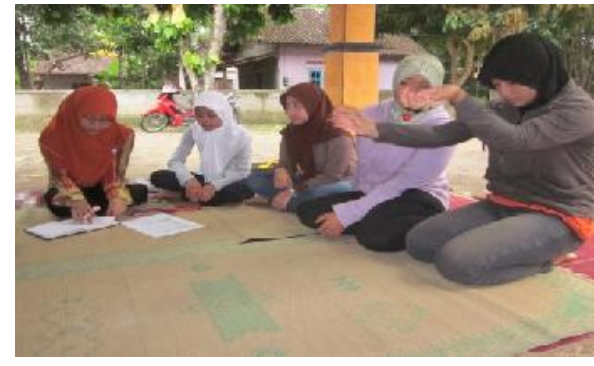

Gambar 2. Sosialisasi ke Pemuda

Mengacu pada pambar 1 di atas terlihat adanya kaitan beberapa aparatur Desa Triharjo. Aparatur desa disini diwakili baik oleh Pak RT dan Pak RW Dusun Gunturan. Pelibatan aparatur desa ini dilakukan untuk meminta izin untuk menyelenggarakan kegiatan pelatihan pada pemuda desa. Izin ini sangat perlu dilakukan agar kegiatan pelatihan ini dapat berjalan lancar tanpa halangan suatu apapun. Selain itu, sosialiasasi ini juga diperlukan agar pemerintah desa terkait dapat membantu memfasilitasi penyelenggara untuk berpartisipasi aktif dalam kegiatan pelatihan. Kegiatan ini sendiri terbuka untuk untuk dimana pesertanya pun tidak hanya difokuskan pada generasi muda saja tapi juga anak-anak, ibu-ibu rumah tangga, bahkan termasuk orang tua.

Gambar 2 di atas dilakukan dengan melibatkan para pemuda sebagai sentral kegiatan. Pemuda punya peran peranan penting dalam kegiatan pelatihan ini. Pemuda Gunturan ini diberikan sosialisasi agar nantinya dapat berkontribusi secara maksimal dalam kegiatan. Kegiatan sosialisasi ini tidak diikuti semua pemuda dusun tersebut. Pemuda yang hadir kebanyakan didominasi oleh kaum perempuan. Namun, hal ini tidak juga menyurutkan niat penyelenggara untuk memaparkan pentingnya menjaga dan melestarikan kesenain gejog lesung di Gunturan agar kesenian ini tak lekang oleh zaman.

2. Kegiatan Pelatihan

Kegaitan pelatihan gejog lesung di Dusun Gunturan, Triharjo, Pandak, Bantul ini dilakukan melalui beberapa tahapan sebagai berikut:

a. Pelatihan Gejong Lesung

Sebelum membahas lebih jauh tentang teknis pelaksaan pelatihan gejog lesung pada pemuda Dusun Gunturan terlebih dulu akan dibahas hal-hal teknis pelaksaannya. Hal teknis yang juga berkaitan erat dengan pelaksanaan kesenian ini adalah alat. Alat disini sejatinya adalah intrumen pendukung yang digunakan sebagai media penunjang utama kegiatan pelatihan. Alat utama dalam kegiatan pelatihan ini adalah Lesung dan Alu. Dua instrumen ini diperuntukkan agar nantinya hasil 


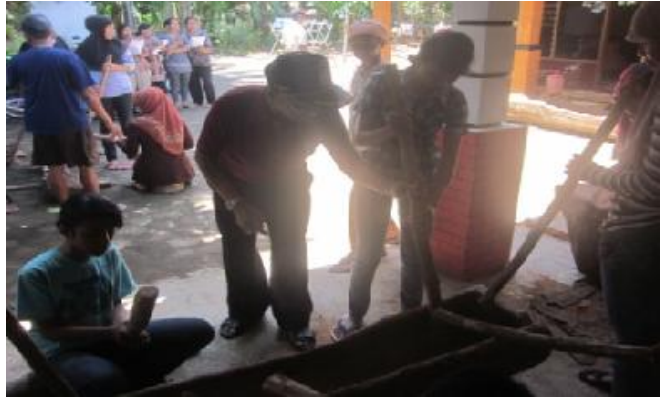

Gambar 3. Pendampingan Pelatih

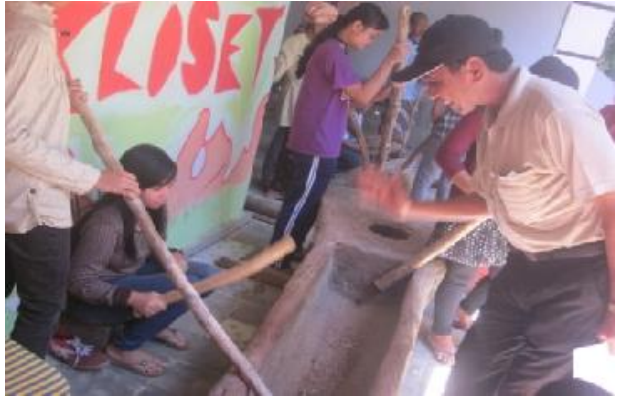

Gambar 4. Penjelasan Bunyi Lesung

Mengacu pada gambar 5 dan 6 di atas terlihat bahwa kegiatan pelatihan kesenian gejog lesung di Dusun Gunturan berjalan dengan baik. Pada dua gambar di atas terlihat para pemuda di dusun ini diberi arahan langsung oleh pakar budaya. Pemuda disini tidak hanya diajarkan bagaimana cara memukul lesung tapi bagaimana agar bunyi yang dihasilkan dari alu tersebut terdengar indah. Peserta pelatihan juga dibagi tugas ada yang memukul lesung dari bagian atas, samping, maupun tengah-tengah atau tepat di lekukan lesung. Setiap pukulan menghasilan bunyi yang berbeda-beda.

Kegiatan pelatihan selain mengajarkan tentang bagaimana cara memukul lesung dengan memakai alu juga diberikan variasi lain. Variasi ini kegiatan ini terlihat dari dimasukkannya lagu-lagu khas Jawa. Pelatih gejog lesung mengajarkan beberapa lagu yang akan dinyanyikan diantaranya

\begin{tabular}{|c|c|}
\hline $\begin{array}{l}\text { Gendhing : Kebo Ilang } \\
\text { Lagu : Suwe Ora Jamu } \\
\text { Suwe ora jamu jamu godhong sawi } \\
\text { Suwe ora ketemu, temu pisan Ibu } \\
\text { Bupati } \\
\text { Suwe ora jamu jamu godhong tomat } \\
\text { Suwe ora ketemu, temu pisan Pak } \\
\text { Camat } \\
\text { Suwe ora jamu jamu godhong } \\
\text { markisah } \\
\text { Suwe ora ketemu, temu pisan karo } \\
\text { Pak Lurah } \\
\text { Suwe ora jamu jamu godhong suruh } \\
\text { Suwe ora ketemu, temu pisan Pak } \\
\text { Dukuh } \\
\text { Suwe ora jamu jamu godhong jambe } \\
\text { Suwe ora ketemu, temu pisan karo } \\
\text { Pak RT } \\
\text { Suwe ora jamu jamu godhong } \\
\text { meniran } \\
\text { Suwe ora ketemu, temu pisan ing } \\
\text { gunturan }\end{array}$ & $\begin{array}{l}\text { Gending : Pung Pung Rek } \\
\text { Lagu : Bantul Projo Taman Sari } \\
\text { Bawa (Pocung) } \\
\text { Pra sedulur Pancasila kang misuwur } \\
\text { Tan ana kang bisa } \\
\text { Ngungkuli sifat kang sekti } \\
\text { Duh pangeran mugi paring lantaran } \\
\text { Tekat ambangun pro wargo sedayane } \\
\text { Wus darbe pamtan mih kelakon } \\
\text { panjangkane } \\
\text { Produktif professional pakayan pra } \\
\text { wargan'e } \\
\text { Bumine subu makmur, sarwo ijo keh } \\
\text { hasile } \\
\text { Tertib aman sap raja kahanane } \\
\text { Sehat jiwa raga resik lingkungane } \\
\text { Yen sinawang tatanan asri ngresepake } \\
\text { Etos keja bantul paja tamansari. }\end{array}$ \\
\hline
\end{tabular}


Dua lagu di atas adalah beberapa lagu yang diajarkan untuk para peserta pelatihan. Lagu tersebut ternyata pada pelaksanaannya dinyanyikan oleh ibu-ibu rumah tangga (IRT). Peran serta ibu IRT ini menegaskan begitu kompaknya warga di dusun ini seperti terlihat dari foto berikut ini:

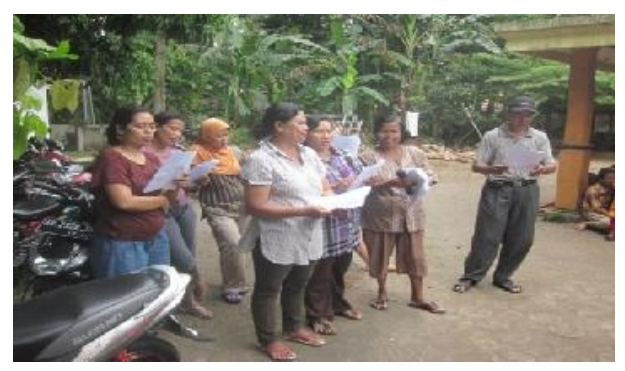

\section{Gambar 5. IRT latihan Nyanyi}

Kegiatan pelatihan pun semakin menarik dengan dimasukkannya latihan dalam menari bagi para peserta. Kegiatan ini difokuskan pada remaja putri yang turut terlibat aktif dalam kegiatan pelatihan. Tari dimasukkan ke dalam pelatihan agar acaranya jadi semakin lebih menarik lagi. Berikut ini adalah foto kegiatan tari di Dusun Gunturan:

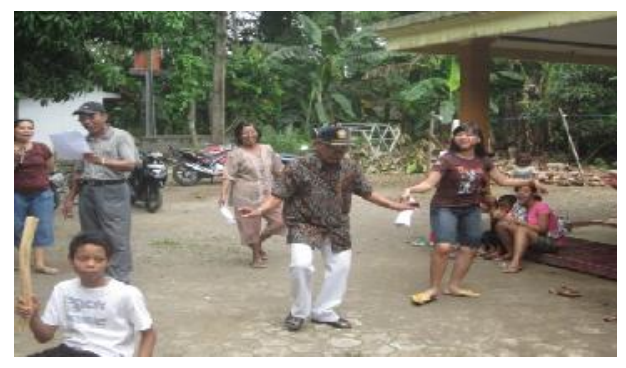

Gambar 6. Pelatihan Tari

Mengacu pada gambar 6 di atas terlihat bahwa tarian dimasukkan untuk memberi warga tersendiri pada peserta pelatihan. Pada gambar tersebut juga terlihat meski peserta pelatihannya baru satu namun terlihat sangat antusias. Tarian ini juga diiringi oleh tabuhan musik gejog lesung yang dimainkan oleh peserta pelatihan lainnya. Perpaduan antara musik gejog lesung, lagu khas jawa, dan tarian diharapkan mampu menghasilkan luaran yang bagus.

\section{Kegiatan Pementasan}

Pada dasarnya kegiatan pementasan dilakukan sebagai muara atau puncak kegiatan.

Pementasana ini dapat dikaji melalui beberapa elemen dasar berikut:

a. Pemain Gejog Lesung

Pemain adalah salah satu unsur utama dalam kegiatan pementasan kesenian Gejog Lesung di Dusun Gunturan, Triharjo, Pandak, Bantul. Pemain yang terlibat dalam kegiatan pementasan kesenian ini adalah sebagai berikut: 


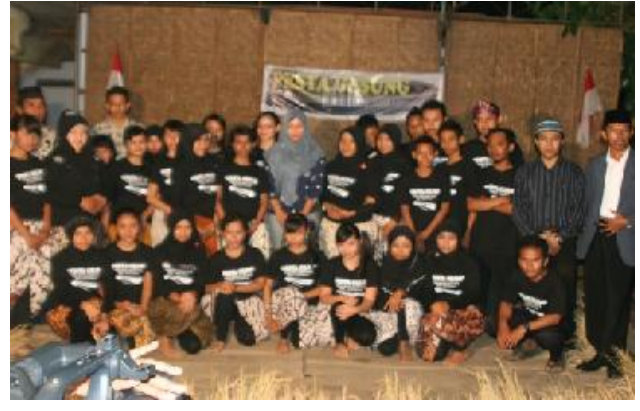

Gambar 7. Peserta Gejog Lesung

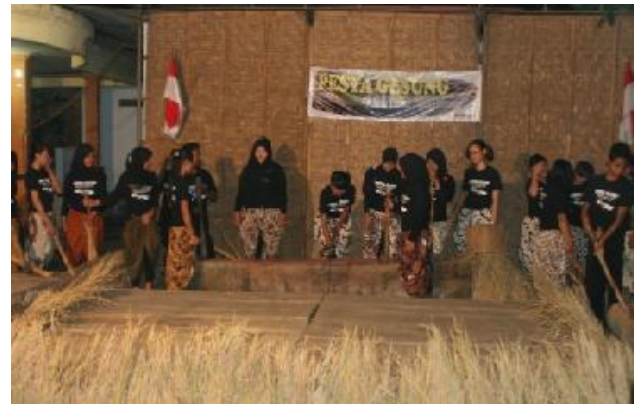

Gambar 8. Permainan Gejog Lesung

Mengacu pada gambar $7 \mathrm{di}$ atas terlihat bahwa personil yang terlibat dalam kegiatan pementasan gejog lesung tersebut banyak. Setiap peserta punya peranan masing-masing ada yang bagian penabuh lesung dengan luaran bunya yang beragam. Kondisi ini diperkuat dengan gambar 8 yang menampilkan kegiatan pementasan di Dusun Gunturan, Triharjo, Pandak, Bantul.

b. Lagu Gejog Lesung

Kegiatan pementasan kesenian gejong lesung awalnya hanya menggunakan lesung sebagai media atau instrumen utama dalam kegiatan pelatihan. Kegiatan seperti ini terasa kurang menarik sehingga perlu ditambah media lain agar kegiatan pementasan berjalan lebih menarik yaitu melalui lagu. Gambar ini dilakukan dengan melibatkan lagu agar kegiatan pementasan menjadi semakin meriah seperti berikut:

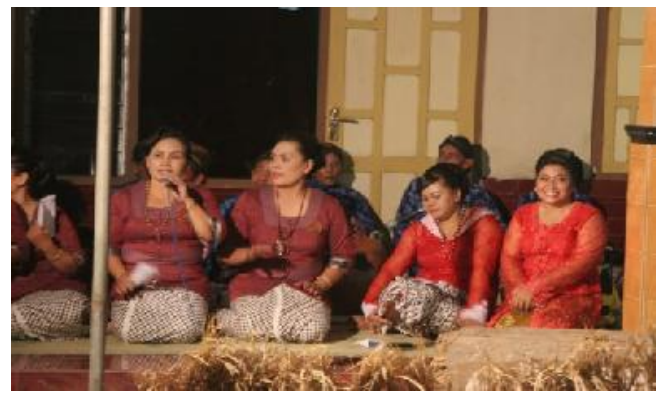

Gambar 9. Lagu Pengiring Gejog Lesung

Mengacu pada gambar $7 \mathrm{di}$ atas terlihat bahwa pihak yang menyanyikan lagu pengiring gejong lesung adalah kaum ibu. Ibu terdiri dari ibu-ibu PKK maupun ibu-ibu rumah tangga. Lagu yang dibawakan oleh kelompok paduan suara ini menganggat tembang khas jawa seperti lagu Kebo Ilang dan Pung-Pung Rek. Keberadaan lagu ini semakin menambah nuansa Jawa dalam pagelaran gejog lesung di Dusun Gunturan.

c. Tari Gejog Lesung

Tari memberikan nuansa lain dalam setiap kegiatan pementasan. Pementasan pada acara gejog lesung yang dilakukan di Dusun Gunturan ini seyogyanya adalah puncak 
dari acara pelatihan pada para pemuda di tempat tersebut. Kegiatan pementasan ini selain menampilkan permainan gejog lesung semata juga ditambahi dengan lagu Kebo Ilang dan Pung-Pung Rek. Selain itu, pementasan ini juga disertai juga dengan tarian untuk memberikan warna agar pelakasaan pementasan berjalan lebih menarik. Para penari dalam kegiatan ini melibatkan pemuda di dusun setempat seperti terlihat dari gambar di bawah ini:

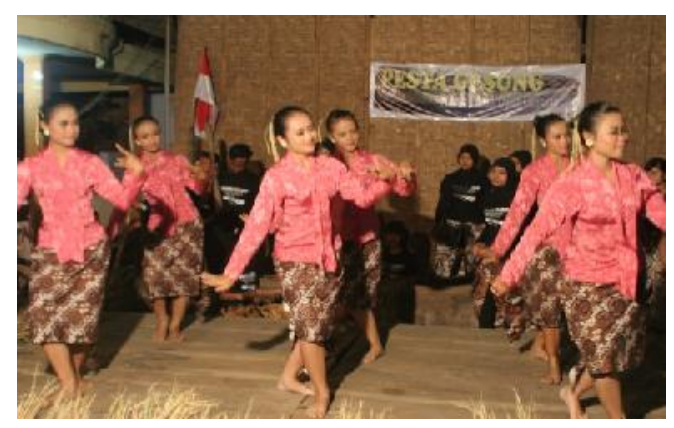

Gambar 9. Pementasan Tari

Kegiatan pementasan tari di Dusun Gunturan ini juga lebih menarik lagi dengan keikutsertaan dari kelompok kesenian Pek Bung. Kelompok kesenian ini juga merupakan salah satu kelompok yang peduli pada pelestarian kesenian gejog lesung. Namun, tidak dipungkiri bahwa kelompok kesenian Pek Bung juga berada diambang batas. Pemain Pek Bung disini banyak didominasi oleh orang sepuh atau orang tua makin memperjelas bahwa masih banyak persoalan yang harus dibenahi agar kesenian sejenis seperti ini dapat terus dilestarikan seperti pada gambar 10 berikut:

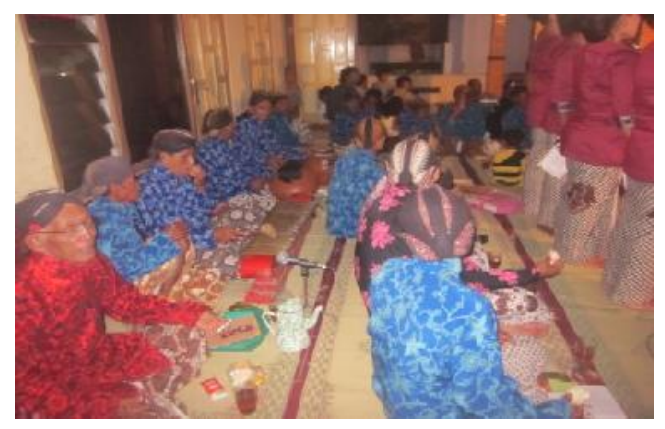

Gambar 10. Kolaboorasi Pek Bung

Mengacu pada gambar 10 di atas terlihat bahwa para pemainnya rata-rata sudah berusia senja. Oleh sebab itu, pelatihan gejog lesung di Dusun Gunturan ini selain untuk ikut berpartisipasi aktif dalam melestarikan kesenian daerah juga sebagai kampanye bagi generasi muda dan pihak lain agar peduli lagi dengan nasib kesenian didaerah mereka. 
Wasis Suprapto ${ }^{1}$, Dodik Kariadi ${ }^{2}$

\section{SIMPULAN}

Berdasarkan hasil dan luaran yang telah dipaparkan di atas maka kesimpulan yang dapat diambil dari kegiatan pelatihan kesenian gejog lesung di Kabupaten Bantul adalah sebagai berikut:

1. Kegiatan pelatihan yang dilakukan di dusun Gunturan, Triharjo, Pandak, Bantul ini dilakukan sebagai upaya untuk melestarikan kesenian gejog lesung yang hampir punah. Upaya pelestarian itu dilakukan melalui tiga kegiatan utama yaitu melakukan sosialisasi pada masyarakat sasaran, melakukan pelatihan, dan melakukan kegiatan pementasan.

2. Kegiatan pelatihan di Dusun Gunturan, Triharjo, Pandak, Bantul ini mendapatkan antusiasme bagi para warga sekitar baik anak-anak, pemuda, ibu rumah tangga (IRT), pihak pemerintahan desa tersebut. Kegiatan ini ternyata memberikan kesadaran lebih bagi warga dusun tersebut hal ini dibuktikan dengan keiikutsertaan kesenian Pek Bung yang juga sudah lama vakum dalam kegiatan pementasan Gejog Lesung.

\section{DAFTAR RUJUKAN}

Aesijah, S. (2011). Makna simbolik dan ekspresi musik kotekan. Harmonia: Journal Of Arts Research And Education, 8(3).

Budiono, H., Widiatmoko, S., Budianto, A., \& Afandi, Z. (2018). Cagar Budaya Kecamatan Badas, Inventaris Rejo, Ngampeng dan Gurah Kabupaten Kediri, 1(2). Retrieved from http://ojs.unpkediri.ac.id/index.php/PPM

Lazuardi, Glery. 2015. Ini 10 Warisan Budaya Indonesia yang Diklaim Malaysia. Jakarta: Tribunnew.com ditulis pada 21 Februari 2015 jam 01:04 WIB

Wahyudiarto, D., \& Kusmayati, H. (2003). Kothekan Lesung Dalam Upacara Ruwatan di Purwopuran, Jawa Tengah. Sosiohumanika. 